\title{
Correlation of Clinical Risk Factors with Diffusion-Weighted Magnetic Resonance Images in Prostate Cancer Patients Treated with Definitive Radiotherapy
}

\author{
Gurcan ERBAY ${ }^{1}$, Cem ONAL ${ }^{2}$, Ozan C. GULER ${ }^{2}$, Elif KARADELI ${ }^{1}$, Zafer KOC ${ }^{1}$ \\ ${ }^{1}$ Baskent University Faculty of Medicine, Department of Radiology, Ankara \\ ${ }^{2}$ Baskent University Faculty of Medicine, Adana Research and Treatment Centre, Department of Radiation Oncology, \\ Adana, TURKEY
}

\begin{abstract}
This study is aimed to correlate apparent diffusion coefficient (ADC) values and clinical T-stage, serum PSA, pathology Gleason scores. We also further analyzed whether ADC values could be used to appropriately define the risk groups. 135 biopsy-proven, radiotherapy-(RT)-treated, prostate cancer patients who underwent pre-RT DW-MRI and standard T2W pelvic MRI were included. ADC and normalized ADC (nADC) values were calculated from DW-MRI delivered a median 8.1 weeks after prostate biopsy. ADC values were correlated with clinical risk factor values by using Pearson correlation test. ADCs in low-, intermediate-, and high-risk patients were $0.873 \pm 0.122 \times 10^{-3} \mathrm{~mm}^{2} / \mathrm{s}, 0.763 \pm 0.124 \times 10^{-3} \mathrm{~mm}^{2} / \mathrm{s}$, and $0.701 \pm 0.132 \times 10^{-3} \mathrm{~mm}^{2} / \mathrm{s}(\mathrm{p}=0.001)$, respectively. Patients with preRT PSA $<10 \mathrm{ng} / \mathrm{mL}$ had significantly higher ADCs than patients with preRT PSA $10-20 \mathrm{ng} / \mathrm{mL}(\mathrm{p}=0.02)$ or $>20 \mathrm{ng} / \mathrm{mL}(\mathrm{p}<$ $0.001)$. Mean ADC for patients with Gleason score $<7$ was significantly higher than patients scoring $7(p=0.001)$ or $>7(p<0.001)$. Clinical stage $<$ T2b patients had significantly higher ADC values versus stage T2b $(p=0.001)$ and T2b tumors $(p<0.001)$. ADC demonstrated stronger correlation with NCCN risk groups $(R=-0.510 ; p<0.001)$. All clinical factors except Gleason score had moderate inverse correlation with nADC. Best nADC correlation occurred with NCCN risk groups $(R=-0.461 ; p<0.001)$. ADCs measured by DW-MRI are noninvasive prognostic markers of clinical parameters and risk for prostate cancer in RT candidates.
\end{abstract}

Keywords: Prostate cancer, Diffusion-weighted MRI, Risk factors, Apparent diffusion coefficient, Prognostic factor

\section{ÖZET}

Definitif Radyoterapi ile Tedavi Edilen Prostat Kanserli Hastalarda Klinik Risk Faktörleri ve Difüzyon Ağırıklı Manyetik Rezonans Görüntülerinin İlişkisi

Bu çalışmanın amacı klinik T evresi, serum prostat spesifik anijen (PSA) ve patolojik Gleason skoru ile apparent diffusion coefficient (ADC) değerlerinin ilişkisini araştırmak. Ayrıca ADC değerlerinin risk gruplarının tanımlanması için uygun olup olmayacağını analiz edilmiştir. Definitif radyoterapi (RT) ile tedavi edilen, tedavi öncesi DA-MRG ve standart T2 ağırıkı MRG'si olan 135 prostat kanserli hasta çalışmaya dahil edildi. Prostat biyopsisinden medyan 8.1 hafta sonra çekilen DA-MRG' lerden ADC ve normalize edilmiş $A D C$ (nADC) değerleri ölçüldü. ADC değerleri ve klinik risk faktörleri arasındaki ilişkiyi araştırmak için Pearson korelasyon testi kullanıldı. Düșük, orta ve yüksek risk hastalarda ADC değerleri sırası ile $0.873 \pm 0.122 \times 10^{-3} \mathrm{~mm}^{2} / \mathrm{s}, 0.763 \pm 0.124 \times 10^{-3} \mathrm{~mm}^{2} / \mathrm{s}$ ve $0.701 \pm 0.132 \times 10^{-3} \mathrm{~mm}^{2} / \mathrm{s}(p=0.001)$ idi. RT öncesi PSA değerleri $<10 \mathrm{ng} / \mathrm{mL}$ olan hastalar, RT öncesi PSA değerleri 10-20 ng/ $\mathrm{mL}(\mathrm{p}=0.02)$ veya $>20 \mathrm{ng} / \mathrm{mL}(\mathrm{p}<0.001)$ olan hastalara göre istatistiksel olarak anlamı derecede yüksek ADC değerlerine sahipti. Gleason Skoru $<7$ olan hastalar için ortalama ADC skoru, gleason $7(p=0.001)$ veya $>7(p<0.001)$ olanlara göre anlamlı derecede yüksekti. Klinik evre $<T 2 b$ olan hastaların ADC değerleri, evre $2 b(p=0.001)$ ve $>2 b(p<0.001)$ hastalara göre anlamlı derecede daha yüksekti. ADC değerleri National Compheresive Cancer Network (NCCN) risk grupları ile kuvvetli bir korelasyon gösterdi(R=-0.510; $p<0.001$ ). Gleason skoru hariç tüm klinik faktörler nADC değeri ile ıımlı ters bir korelasyon içindeydi. nADC' nin en iyi korelasyonu NCCN risk grupları ileydi. ( $R=-0.461 ; p<0.001)$. DA-MRG ile ölçülen ADC değerleri, RT planlanan prostat kanserli hastalarda önemli bir non invaziv prognostik belirteç olarak değerlendirilebilir.

Anahtar Kelimeler: Apparent difüzyon katsayısı, Difüzyon ağıllıkı MRG, Prognostik faktör, Prostat kanseri, Risk faktörleri 


\section{INTRODUCTION}

Prostate cancer is mostly an indolent tumor with slow disease progression. However one of six men had prostate cancer, but only one of 36 patients died with disease. Treatment strategies include watchful waiting, radical prostatectomy, or radiotherapy (RT) with or without hormonotherapy, depending on disease stage and risk factors. ${ }^{1-3}$ The challenge of managing localized prostate cancer is to distinguish patients who may benefit from radical treatment from patients who do not need any intervention. Furthermore, in patients treated with RT, treatment strategies depend on clinical parameters and, notably, risk groups.

Currently, serum prostate-specific antigen (PSA), clinical $\mathrm{T}$ stage, and Gleason scoring are used for defining prostate cancer risk. ${ }^{4,5}$ These risk factors have been used to predict the biochemical relapse after surgery or RT, and these parameters are also used to make treatment choices. Additionally, PSA doubling-time and PSA density are used to predict disease outcome, but they are nonspecific in determining diseases prognosis. ${ }^{6,7}$ To predict tumor biological behavior, histological evaluation of the prostate is required. However, histological evaluation involves invasive biopsy procedure(s) and is subject to sampling error. Furthermore, histopathological findings of prostatectomy and biopsy specimens do not always accurately reflect actual disease status. ${ }^{8} 9$ There may be discordance between clinical and pathological staging, and Gleason scores of biopsy and prostatectomy specimens may vary. For this reason, a thorough evaluation of entire prostate is essential before performing definitive RT, in which histopathological evaluation is based on prostate biopsy only, and staging is performed with clinical and radiological findings. Non-invasive methods to evaluate the entire prostate and the tumor biology before performing RT may be a promising alternative. Moreover, this approach would allow optimized treatment delivery to adequately stratified patient risk groups.

The best method of imaging prostate cancer is endorectal T2-weighted magnetic resonance imaging (MRI), which has $60-82 \%$ sensitivity and $55-70 \%$ specificity for detecting cancer. ${ }^{10-12}$ Additionally, recent studies have aimed to determine the value of
MR correlates of cellular density, metabolite concentration, and tumor vascularization for predicting tumor aggressiveness. ${ }^{13-16}$ Diffusion-weighted MRI (DW-MRI) is advantageous in tumor localization. ${ }^{17-19}$ DW-MRI may also provide qualitative information regarding the pathophysiological character of prostate cancer. ${ }^{18,20,21}$ DW-MRI is sensitive to the microscopic motion of water molecules and allows biological characterization of tissues based on their water-diffusion properties. The degree of diffusion is quantified as the apparent diffusion coefficient (ADC).

Few clinical studies involving limited patient numbers have evaluated the potential value of pre-prostatectomy DW-MRI as a non-invasive marker of disease aggressiveness. ${ }^{22,23}$ This study assessed the potential importance of ADC values obtained from DW-MRI in prostate cancer patients treated with definitive RT. Additionally; we analyzed the correlation between ADC values and clinical T-stage, serum PSA levels, and Gleason scores. We further analyzed whether ADC values could be used to appropriately define the risk groups.

\section{PATIENTS AND METHODS}

\section{Study Design and Patient Population}

This retrospective study was approved by Baskent University Institutional Review Board (Project No \#KA13/146) and was supported by the Baskent University Research Fund. The requirement for receipt of written informed consent was waived due to the retrospective nature of this study and because all patient-identifying information was anonymized. All study protocols adhered to the tenets of the Declaration of Helsinki. We reviewed the records of 135 patients with biopsy-proven prostate cancer at the Baskent University Faculty of Medicine who were treated with curative intent using definitive RT between January 2012 and August 2013 and who had undergone both DW-MRI and standard T2W pelvic MRI before RT.

Patients were stratified into three risk groups according to the National Comprehensive Cancer Network (NCCN) guidelines. ${ }^{24}$ The low-risk group contained patients with T1-T2a tumor, Gleason score $<7$, and PSA $<10 \mathrm{ng} / \mathrm{mL}$; intermediate-risk 
patients were $\mathrm{T} 2 \mathrm{~b}$ tumor, Gleason score $=7$, and PSA $10-20 \mathrm{ng} / \mathrm{mL}$; and high-risk patients were $\geq$ T3a tumor, Gleason score $>7$, and PSA $>20 \mathrm{ng} /$ $\mathrm{mL}$. Pre-RT MRI scans were performed a median 8.1 weeks (range 4.3-34.1 weeks) after initial prostate biopsy and cancer diagnosis.

\section{Magnetic Resonance Imaging}

For all patients, T2W, fat-saturated T2W, DWI, and Dynamic Contrast Imaging- (DCE)-MRI exam were performed using a 1.5 T Siemens Avanto ${ }^{\circledR}$ MR scanner used as an 8-element, phased-array coil during the scans, without an endorectal coil. $\mathrm{T} 2 \mathrm{~W}$ images were acquired with a fast spin-echo sequence: repetition time/echo time $(\mathrm{TR} / \mathrm{TE})=$ $5480 / 55 \mathrm{~ms}$, acquisition matrix $224 \times 320$, field of view $(F O V)=220 \mathrm{~cm}$, slice thickness $4 \mathrm{~mm}$, and intersection gap $1.6 \mathrm{~mm}$. Fat-saturation turbo spin echo sequence imaging parameters were: TR/ $\mathrm{TE}=5480 / 55 \mathrm{~ms}$, echo train length $=40$, acquisition matrix $224 \times 320, F O V=220 \mathrm{~cm}$, slice thickness $=1.6 \mathrm{~mm}$. DW-MRI scans were performed using a multi-slice, single-shot, spin-echo, planar imaging (SE-EPI) sequence $(\mathrm{FOV}=365 \mathrm{~cm}$, slice thickness $=4 \mathrm{~mm}$, EPI-factor $=192$, intersection gap $=0 \mathrm{~mm}, \mathrm{TR} / \mathrm{TE}=4400 / 83 \mathrm{~ms}$, acquisition matrix $=192 \times 100,4$ averages, sense factor $=2$ in the anterior-posterior direction. The b-values of 0,200, 600 , and $1000 \mathrm{~s} / \mathrm{mm}^{2}$ were used to calculate ADC. The ADC maps were generated automatically using multi-exponential data fitting with manufacturer's software (syngo.via; Siemens Healthcare, Erlangen, Germany). The DCE-MRI protocol consisted of a three-dimensional, spoiled-gradient echo sequence $(3 \mathrm{~mm}$ section thickness, TR/TE $=$ $6.7 / 3.14 \mathrm{~ms}$, flip angle $10^{\circ}, \mathrm{FOV}=200 \mathrm{~cm}$, acquisition matrix $=154 \times 256$. For DCE imaging, a dose of $0.1 \mathrm{~mL} / \mathrm{kg}$ gadoterate meglumine (Dotarem ${ }^{\circledR}$; Guerbet Group, LLC., Villepinte, France) was injected at $2 \mathrm{~mL} / \mathrm{s}$, followed by a saline flush.

\section{Data Analysis}

Prostate cancer localization was determined by consensus of the two experienced genitourinary radiologists ( $\geq 20$-years experience) based on a comparison of digital rectal examination findings, pathologic biopsy results with four-quadrate and 12 core biopsy, and the presence of focal low-signal-intensity areas in the peripheral and/or transition zones on ADC maps, with using T2W. ADCs were determined and maps created using Siemens workstation software syngo.via. Diagnostic criteria of prostate cancer in MRI findings were: focal area(s) revealing low signal intensity on T2W images and focal lesion restriction on ADC maps,

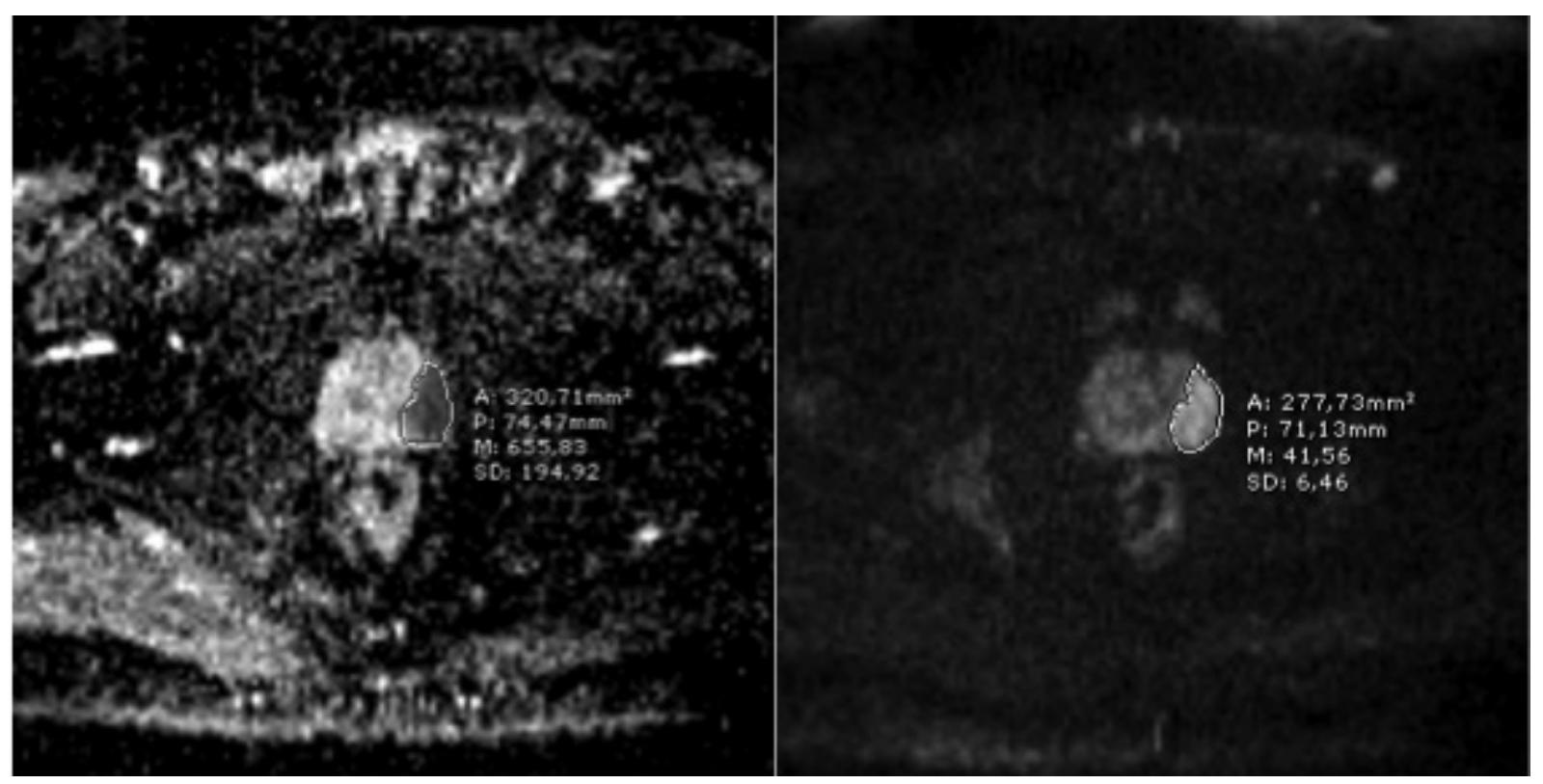

Figure 1. Axial apparent diffusion coefficient map of a corresponding patient demonstrating prostate tumor at left periheral zone. 


\begin{tabular}{|lll|}
\hline \multicolumn{2}{|l|}{ Table 1. Patient characteristics } \\
\hline Characteristics & No of patients & Percent (\%) \\
\hline Age, median (range), yrs & $68(52-84)$ & \\
Stage & & \\
T1c & 66 & 49 \\
T2a & 8 & 6 \\
T2b & 26 & 20 \\
T2c & 7 & 5 \\
T3a & 6 & 4 \\
T3b & 22 & 16 \\
Gleason score & & \\
3+3 & 72 & 53 \\
3+4 & 25 & 19 \\
$4+3$ & 20 & 15 \\
$4+4$ & 6 & 4 \\
$4+5$ & 10 & 7 \\
$5+5$ & 2 & 2 \\
Risk groups & & \\
Low & 41 & 30 \\
Intermediate & 34 & 25 \\
High & 60 & 45 \\
& & \\
\hline
\end{tabular}

early contrast enhancement with fast washout, and high blood vessel permeability on dynamic contrast-enhanced images. ${ }^{25,26}$ Additionally, prostate tumors were seen as hyperintense lesions with high b-values.

First, both hyperintense lesions at high b-values (especially $b=800$ or $b=1000$ ) and lesion with diffusion restriction on ADC maps were, when colocalized in the same area, determined to be focal prostatic cancer lesions (Figure 1). Before RT, regions of interest (ROIs) of the tumors in the peripheral and/or transition zones were drawn on ADC maps to include as much of the tumor as possible, calculations were performed twice in the same site, and the average of these two values was calculated. If a tumor was located in several ADC map imaging slices, ADC values were measured on both the biggest and the most homogenous regions of the same slice. When the ROIs were drawn, great care was taken to exclude both the neurovascular bundle and the urethra to reduce ADC calculation error. For measuring ADC values in the peripheral and/or transition zones of benign tissue, ROIs at the contralateral side of the tumor were selected. Additionally, the normalized ADC (nADC) was calculated as the ratio of tumor ADC to normal prostate tissue ADC.

\section{Statistical Analysis}

Statistical analyses were performed using SPSS software version 20 (SPSS Inc./IBM, Chicago, IL). Clinical risk factors including Gleason score, clinical T-stage, and serum PSA level were categorized into three groups. A paired Student t-test and an independent samples t-test with Bonferroni correction were used to assess differences between groups. Pearson correlation analysis was performed between ADCs, nADCs, and clinical risk factor values. Receiver operating characteristic (ROC) analysis was performed to assess the power of tumor $\mathrm{ADC}$ and $\mathrm{nADC}$ in discriminating between low-, intermediate-, and high-risk groups and a cut-off value for this parameter was determined. A $p$ value of $<0.05$ was considered indicative of statistically significant differences.

\section{RESULTS}

Patient characteristics are summarized in Table 1. Almost half of the patients had clinical stage T1c tumors or Gleason score 3+3 tumors. Again almost one-third of patients were stratified into the lowrisk group, while the remaining two-thirds of patients were in the intermediate- or high-risk group. The overall mean and median serum PSA levels were $23.3 \pm 8.0 \mathrm{ng} / \mathrm{mL}$ and $12.6 \mathrm{ng} / \mathrm{mL}$ (range 1.6$119.6 \mathrm{ng} / \mathrm{mL}$ ), respectively.

\section{ADC Measurements}

The mean tumor $\mathrm{ADC}$ and $\mathrm{nADC}$ values were $(0.773 \pm 0.141) \times 10^{-3} \mathrm{~mm}^{2} / \mathrm{s}$ and $(0.581 \pm 0.122) \times 10^{-3}$ $\mathrm{mm}^{2} / \mathrm{s}$, respectively. The ADC values in the central and peripheral normal prostate tissue were $(1.321 \pm 0.156) \times 10^{-3} \mathrm{~mm}^{2} / \mathrm{s}$ and $(1.338 \pm 0.152) \times 10^{-3}$ $\mathrm{mm}^{2} / \mathrm{s}$, respectively.

\section{Correlation with Serum PSA}

The mean ADC values for PSA groups $<10$ $\mathrm{ng} / \mathrm{mL}, \quad 10-20 \mathrm{ng} / \mathrm{mL}$ and $>20 \mathrm{ng} / \mathrm{mL}$ were $(0.836 \pm 0.122) \times 10^{-3} \quad \mathrm{~mm}^{2} / \mathrm{s}, \quad(0.751 \pm 0.130) \times 10^{-3}$ $\mathrm{mm}^{2} / \mathrm{s}$, and $(0.690 \pm 0.141) \times 10^{-3} \mathrm{~mm}^{2} / \mathrm{s}$, respectively (Figure 2A). Patients with low preRT PSA levels $<10 \mathrm{ng} / \mathrm{mL}$ had significantly higher ADC 

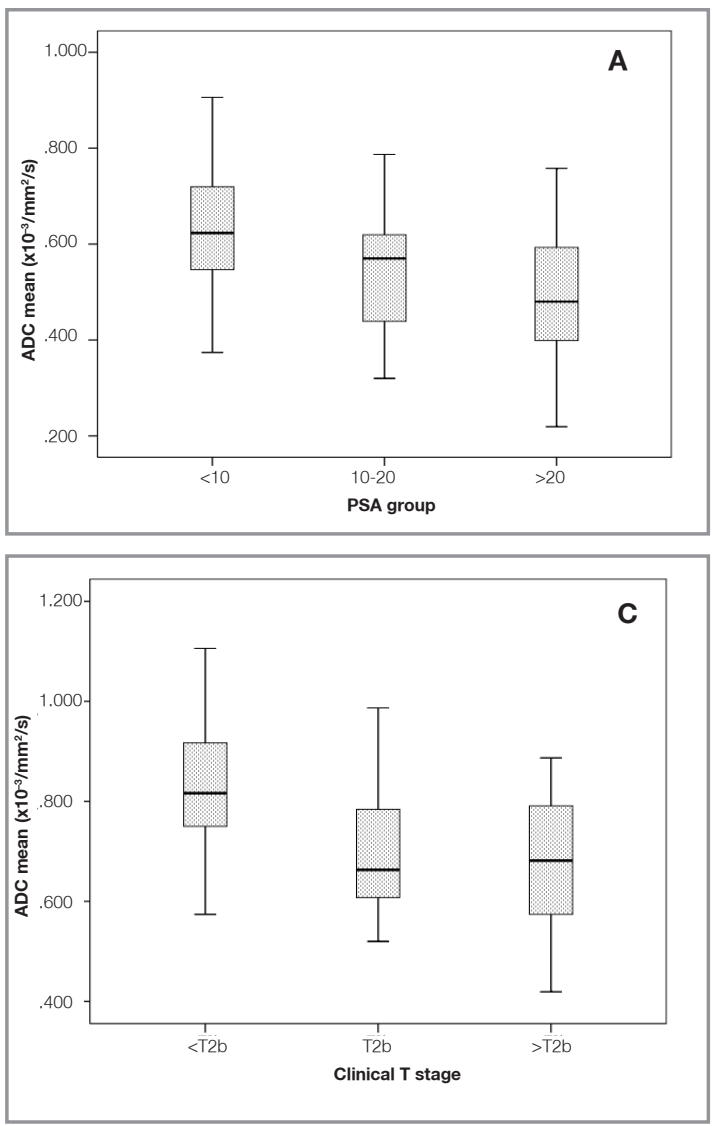

Figure 2. ADC values measured in diffusion-weighted magnetic resonance imaging before radiotherapy according to (A) PSA levels, (B) Gleason scores (C) clinical T-stage, and (D) risk groups.

values compared to patients with preRT PSA $10-20$ $\mathrm{ng} / \mathrm{mL}(\mathrm{p}=0.02)$, and PSA $>20 \mathrm{ng} / \mathrm{mL}(\mathrm{p}<0.001)$. However there was no significant difference between ADC values of patients with intermediate PSA $10-20 \mathrm{ng} / \mathrm{mL}$ and PSA $>20 \mathrm{ng} / \mathrm{mL}(\mathrm{p}=0.2)$ levels.

\section{Correlation with Tumor Gleason Scores}

The mean ADC for patients with Gleason scores $<7 \quad\left(0.829 \pm 0.119 \times 10^{-3} / \mathrm{mm}^{2} / \mathrm{s}\right)$ was significantly higher than in patients with Gleason score 7 $\left(0.720 \pm 0.135 \times 10^{-3} \mathrm{~mm}^{2} / \mathrm{s} ; \mathrm{p}=0.001\right)$ and $\mathrm{pa}-$ tients with Gleason score $>7\left(0.624 \pm 0.109 \times 10^{-3}\right.$ $\mathrm{mm}^{2} / \mathrm{s} ; \mathrm{p}<0.001$ ) (Figure 2B). However, the difference between Gleason score 7 and Gleason score $>7$ approached statistical significance $(p=$ $0.08)$.

\section{Correlation with Tumor Stage}

Patients with clinical stage $<\mathrm{T} 2 \mathrm{~b}$ tumors had significantly higher ADC values $\left(0.832 \pm 0.117 \times 10^{-3}\right.$ $\mathrm{mm}^{2} / \mathrm{s}$ ) compared to patients with stage-T2b tumors $\left(0.708 \pm 0.135 \times 10^{-3} \mathrm{~mm}^{2} / \mathrm{s} ; \mathrm{p}=0.001\right)$, and stages $>$ T $2 \mathrm{~b}$ tumors $\left(0.673 \pm 0.127 \times 10^{-3} \mathrm{~mm}^{2} / \mathrm{s} ; \mathrm{p}\right.$ $<0.001$ ) (Figure 2C). However there was no significant difference between $\mathrm{ADC}$ values of patients with clinical stage $\mathrm{T} 2 \mathrm{~b}$ tumor and $>\mathrm{T} 2 \mathrm{~b}$ tumors $(\mathrm{p}=$ $0.6)$.

\section{Correlation with NCCN Risk Groups}

We stratified patients into risk groups based on composites of Gleason score, serum PSA levels, and tumor stage. The ADC values in low-, intermediate-, and high-risk patient groups were $(0.873 \pm 0.122) \times 10^{-3} \quad \mathrm{~mm}^{2} / \mathrm{s}, \quad(0.763 \pm 0.124) \times 10^{-3}$ $\mathrm{mm}^{2} / \mathrm{s}$, and $(0.701 \pm 0.132) \times 10^{-3} \mathrm{~mm}^{2} / \mathrm{s}$, respectively (Figure 2D). The differences between all paired risk group comparisons were significant. 

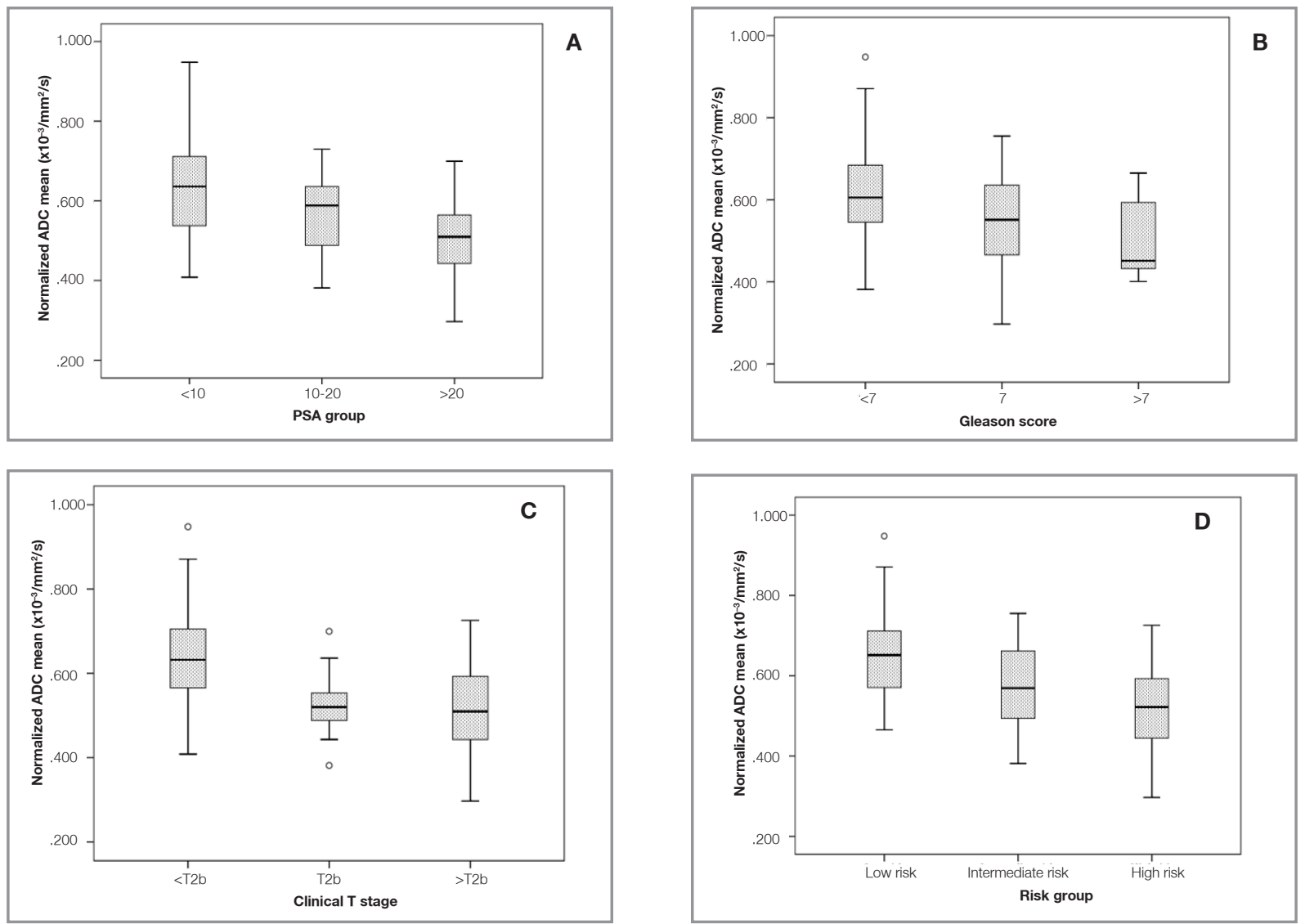

Figure 3. Normalized ADC values measured in diffusion-weighted magnetic resonance imaging before radiotherapy according to (A) PSA levels, (B) Gleason scores (C) clinical T-stage, and (D) risk groups.

\section{Normalized ADC Measurements}

The mean $\mathrm{nADC}$ values for PSA groups $<10 \mathrm{ng} /$ $\mathrm{mL}, 10-20 \mathrm{ng} / \mathrm{mL}$, and $>20 \mathrm{ng} / \mathrm{mL}$ were 0.63 , 0.57 , and 0.51 , respectively (Figure $3 \mathrm{~A}$ ). The only significant difference in nADC values existed between patients with PSA $<10 \mathrm{ng} / \mathrm{mL}$ versus patients with PSA $>20 \mathrm{ng} / \mathrm{mL}(\mathrm{p}=0.001)$. The mean nADC for patients with Gleason score $<7$ (0.62) was significantly higher than patients with Gleason score $7(0.55 ; p=0.04)$ and patients with Gleason score $>7(0.50 ; p=0.03)$ (Figure 3B). However, the nADC difference between Gleason score 7 and Gleason score $>7$ groups did not reach statistical significance $(\mathrm{p}=0.6)$. Patients with clinical stage $<$ T2b tumors had significantly higher nADC values (0.63) compared to patients with clinical stage $\mathrm{T} 2 \mathrm{~b}$ tumors $(0.53 ; \mathrm{p}=0.04)$ and stage $>\mathrm{T} 2 \mathrm{~b}$ tumors $(0.51 ; p=0.001)$ (Figure 3C). However, there was no significant difference between $\mathrm{nADC}$ values of patients with clinical stage $\mathrm{T} 2 \mathrm{~b}$ tumors versus $>\mathrm{T} 2 \mathrm{~b}$ tumors $(\mathrm{p}=0.9)$. The nADC values in the low-, intermediate-, and high-risk patients were $0.66,0.58$, and 0.52 , respectively (Figure 3D). The nADC differences between low- versus intermediate-risk groups ( $\mathrm{p}=0.04)$, and low- versus high-risk groups $(\mathrm{p}<0.001)$ were significant. No significant difference in $\mathrm{nADCs}$ existed between the intermediateand high-risk groups.

\section{Correlation Between Clinical Factors}

Significant and inverse moderate correlations between all clinical factors and ADCs were observed (Table 2). The ADC demonstrated the best correlation with the NCCN risk groups (Pearson=-0.510; $\mathrm{p}<0.001)$. All clinical factors except the Gleason score were inversely and moderately correlated with nADCs. As with the ADC, the best correlation with nADC was observed with the NCCN risk groups (Pearson $=-0.461 ; \mathrm{p}<0.001$ ). 


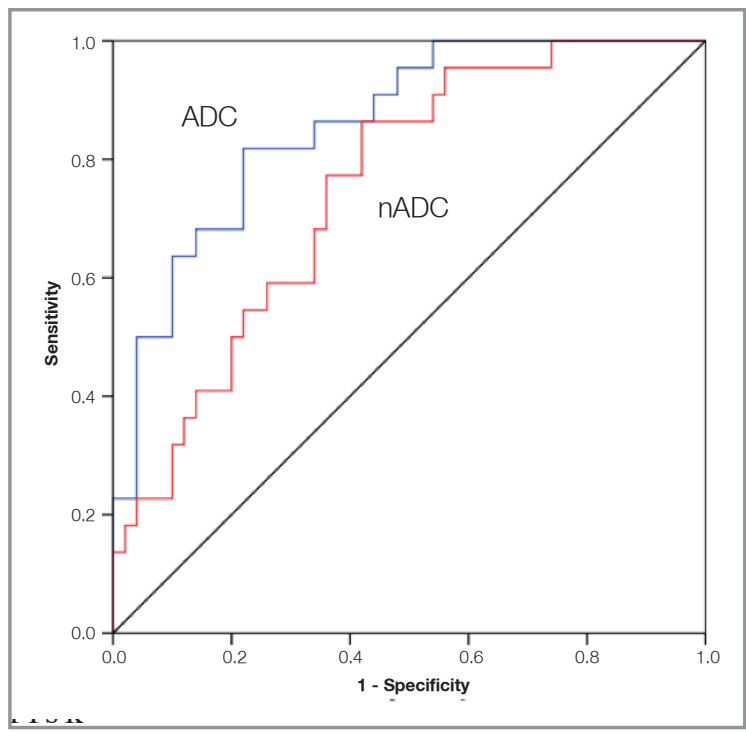

Figure 4. Receiver operating characteristic curve analysis in risk group prediction according to ADC and nADC.

prediction accuracy, a nADC cut-off value of 0.59 gave a sensitivity of $68 \%$ and specificity of $66 \%$.

\section{DISCUSSION}

This study demonstrates that ADC values can distinguish between among the clinical parameters and define risk factors that are used when selecting RT strategies for treating prostate cancer. In low-risk patients, prostate RT is adequate treatment, whereas in intermediate- and high-risk patients, hormone therapy is delivered concurrently with RT. Additionally, negative correlations were found between ADC values and clinical parameters including serum PSA level, clinical T-stage, and Gleason score.
Water diffusion characteristics are substantially affected by cellular and structural changes within tissues, including cell density, vascularity and microvascular tortuosity, extracellular fluid viscosity, membrane permeability between intra- and extracellular compartments, active transport and flow, and directionality of tissue/cellular structures that impede water mobility. ${ }^{27}$ These cellular and structural differences exist between low- and high-risk lesions, and they can be measured non-invasively in vivo using DW-MRI, which constructs images based on quantifying water molecule diffusion within tissues. ${ }^{28}$

The ADC is a quantitative parameter of the extent of water molecule diffusion. Due to increased cellularity, decreased extracellular space, and abnormal microvasculature, tumor ADCs are generally lower than surrounding normal tissues. Furthermore, ADC values can potentially be used to predict tumor aggressiveness. ${ }^{22,29,30} \mathrm{Bae}$ et $\mathrm{al} .{ }^{22}$ demonstrated that prostate cancer patients with a Gleason score $\geq 4+3$, larger tumors $(\geq 16 \mathrm{~mm})$, and highly proliferating cancers had significantly lower ADC values in 29 patients treated with radical prostatectomy. Oto et al. ${ }^{29}$ found a moderate negative correlation between Gleason score ( $\mathrm{r}-0.376$, $\mathrm{p}=0.001$ ) and tumor $\mathrm{ADC}$ values in 73 prostate cancer patients treated with radical prostatectomy. In 39 patients treated with radical prostatectomy, Thörmer et al. ${ }^{21}$ found that nADC could be used as a valuable surrogate for predicting tumor aggressiveness. deSouza et al. ${ }^{23}$ demonstrated significant differences in ADC values between patients at low-risk and those with higher-risk localized prostate cancer. We evaluated more patients compared to these previous studies, and we demonstrated a significant correlation between ADCs and diverse clinical parameters and NCCN risk groups.

\begin{tabular}{|lllll|}
\hline \multicolumn{2}{|l|}{ Table 2. Correlation between ADC, nADC and clinical prognostic parameters } \\
\hline \multirow{2}{*}{ Parameter } & ADC & & & nADC \\
\cline { 2 - 4 } & $\begin{array}{l}\text { Pearson correlation } \\
\text { coefficient }\end{array}$ & $\mathbf{p}$ & & $\begin{array}{l}\text { Pearson correlation } \\
\text { coefficient }\end{array}$ \\
\hline PSA & -0.443 & $<0.001$ & -0431 & $<$ \\
Gleason score & -0.496 & $<0.001$ & -0.351 & $<0.001$ \\
Clinical T stage & -0.501 & $<0.001$ & -0.430 & $<0.001$ \\
Risk groups & -0.510 & $<0.001$ & -0.461 & $<0.001$ \\
\hline
\end{tabular}


All patients had been treated with definitive RT. Therefore, we could not perform a detailed analysis of histopathological correlations with ADC values. In some cases, there may be discordance between histopathological findings in biopsy and prostatectomy specimens. Previous studies have shown significant pathologic upgrading at radical prostatectomy, with reported upgrading percentages ranging from $20.3 \%-54 \% .{ }^{15}$ This potentially creates a problem with accurately identifying and monitoring patients who are erroneously categorized as having low-risk disease before surgery. For defining NCCN risk groups, patients were stratified according to Gleason score, serum PSA level, and clinical T-stage. Although ADC values are known to correlate with tissue structure, the NCCN criteria rather than Gleason score were used to define risk groups, to reduce the effects of biopsy sampling variability and reflect that our ADC values were averaged over the whole tumor ROI. Averaging ADCs over the ROI is a limitation, as it does not account for ADC differences within the tumor itself; therefore, correlation of these differences with histopathology would be useful. Further study of DW-MRI in localized prostate cancer is also warranted to assess its correlative utility in relation to tumor histopathology and clinical outcomes.

Although several study evaluated ADCs for determining tumor aggressiveness, few studies defined the cut-off values to predict high-grade cancer foci. ${ }^{21-23}$ Bae et al. ${ }^{22}$ determined the cut-off ADC value of $0.52 \times 10^{-3} \mathrm{~mm}^{2} / \mathrm{s}$ as having low- versus high-grade tumors. deSouza et al. ${ }^{23}$ found that ADC cut-off values of $1.33 \times 10^{-3} \mathrm{~mm}^{2} / \mathrm{s}$ (sensitivity $89 \%$, specificity $58 \%$ ) and $1.20 \times 10^{-3} / \mathrm{mm}^{2} / \mathrm{s}$ (sensitivity $55 \%$, specificity $95 \%$ ) provided $70 \%$ of risk prediction. Thörmer et al. ${ }^{21}$ defined nADC values below 0.46 as the threshold for tumors with intermediate or high aggressiveness. The ADC cutoff values may vary between studies because of different enrolled patient numbers and varied ADC measurement techniques. In our study we evaluated both ADC and nADC values. We found that for $70 \%$ risk prediction, an ADC cut-off of $0.802 \times 10^{-3}$ $\mathrm{mm}^{2} / \mathrm{s}$ gave a sensitivity of $82 \%$ and specificity of $78 \%$, and a nADC cut-off value of 0.59 gave a sensitivity of $68 \%$ and specificity of $66 \%$. Although our ADC and nADC cut-off values were higher than previously reported findings, our results may be more reliable because we studied larger number of patients.

ADC value measurement has not been standardized yet. In some studies, minimum ADC values were correlated with tumor biological aggressiveness $^{31,32}$, whereas other researchers used mean $\mathrm{ADC}$ values as a surrogate for tumor aggressiveness. ${ }^{22,33}$ Although there is intratumoral heterogeneity in prostate cancer, we used the mean ADC values. However, to minimize ADC measurement error, ADC was measured on much larger tumor volumes that previously studied, by averaging ADC maps of several imaging slices.

The main limitation of $\mathrm{T} 2 \mathrm{~W}$ imaging is false positivity for low-signal intensity lesions, where infection, inflammation, and fibrosis may mimic the tumor. In this study, to diminish false results, the radiologists delineating the ROI were aware of the tumor localization that was verified with biopsy. However, on post-biopsy T2W images, hemorrhage has low signal intensity that can mimic the tumor and lead to inaccurate measurements. ${ }^{27}$ In previous studies analyzing the importance of ADC in prostate cancer patients ${ }^{22,23}$, the MRI scans were delivered before prostate biopsy, which makes the result more accurate. We evaluated the patients before initiation of RT, and MRI scans were all taken before RT with biopsy proven prostate cancer. In suspected cases, T1W images of the whole pelvis were taken at the same time to differentiate hemorrhage and minimize artifactual error introduction into ADC measurements.

A major limitation of this study is the lack of correlating tumor ROIs with whole-mount histopathology sections, because all patients in this study were treated with definitive RT. In the high-risk cohort, all lesions were large and easily discernible on T2W imaging, so the likelihood of error in ROI selection is low. In the low-risk cohort, where all lesions were verified with biopsy data, the ADC values were likely to have been indistinguishable from adjacent non-malignant prostate tissue. In these cases, the lack of a visually identifiable lesion on the ADC map is also an indicator of the low-risk nature of the lesion. A more problematic feature is 
that we used the averaged ADC from the entire tumor region, and this was often heterogeneous. It may be that the more diffusion-restricted areas within the tumor region are ultimately more predictive of outcome. Also, the absolute cut-off values for the ADC and nADC have not yet been appropriately defined and standardized, because prior studies used different measurement techniques and were prone to inter-observer variability. The images in our study were interpreted by consensus of two readers rather than by separate analyses. The purpose of this study, however, was not to assess ADC diagnostic accuracy for predicting localized prostate cancer by DW-MRI but to correlate the ADC values with clinical rsik factors using 1.5T MRI. Another study limitation was that all patient underwent transrectal sonography guided-biopsy with pretreatment MR examination, which might have had potential effects on subsequent ADC measurement due to hemorrhage or inflammatory changes in the normal prostate tissue.

In conclusion, DW-MRI offers potential to evaluate prostate cancer patients treated with definitive RT, where complete histopathological evaluation of the entire prostate is not possible. We found that ADC values measured using DW-MRI can noninvasively determine clinical parameters and risk groups for prostate cancer patients that have prognostic significance. However, further work is needed to conclusively determine the clinical significance of using ACDs to define risk groups and to evaluate treatment responses after definitive RT for prostate cancer.

\section{REFERENCES}

1. Heidenreich A, Bastian PJ, Bellmunt J, et al. EAU guidelines on prostate cancer. Part II: Treatment of advanced, relapsing, and castration-resistant prostate cancer. Eur Urol 65: 46779, 2014.

2. Onal C, Topkan E, Efe E, et al. The effect of concurrent androgen deprivation and $3 \mathrm{D}$ conformal radiotherapy on prostate volume and clinical organ doses during treatment for prostate cancer. Br J Radiol 82: 1019-26, 2009.

3. Chism DB, Hanlon AL, Horwitz EM, et al. A comparison of the single and double factor high-risk models for risk assignment of prostate cancer treated with 3D conformal radiotherapy. Int J Radiat Oncol Biol Phys 59: 380-5, 2004.
4. Albertsen PC, Hanley JA, Gleason DF, et al. Competing risk analysis of men aged 55 to 74 years at diagnosis managed conservatively for clinically localized prostate cancer. JAMA 280: 975-80, 1998.

5. Vickers AJ, Thompson IM, Klein E, et al. A Commentary on PSA Velocity and Doubling Time for Clinical Decisions in Prostate Cancer. Urology 83: 592-98, 2014.

6. Hegde JV, Mulkern RV, Panych LP, et al. Multiparametric MRI of prostate cancer: an update on state-of-the-art techniques and their performance in detecting and localizing prostate cancer. J Magn Reson Imaging. 37: 1035-54, 2013.

7. Truesdale MD, Cheetham PJ, Turk AT, et al. Gleason score concordance on biopsy-confirmed prostate cancer: is pathological re-evaluation necessary prior to radical prostatectomy? BJU Int107: 749-54, 2011.

8. Kupka R, Dall'oglio MF, Sant'ana AC, et al. Can single positive core prostate cancer at biopsy be considered a low-risk disease after radical prostatectomy? Int Braz J Urol 39: 8007, 2013

9. Shoji S, Hiraiwa S, Endo J, et al. Manually controlled targeted prostate biopsy with real-time fusion imaging of multiparametric magnetic resonance imaging and transrectal ultrasound: An early experience. Int J Urol 22:173-8, 2015.

10. Tilak G, Tuncali K, Song SE, et al. $3 T$ MR-guided in-bore transperineal prostate biopsy: A comparison of robotic and manual needle-guidance templates. J Magn Reson Imaging, (in press) 2014.

11. Le JD, Tan N, Shkolyar E, et al. Multifocality and prostate cancer detection by multiparametric magnetic resonance imaging: correlation with whole-mount histopathology. Eur Urol 67: 569-76, 2015.

12. Hambrock T, Somford DM, Huisman HJ, et al. Relationship between apparent diffusion coefficients at 3.0-T MR imaging and Gleason grade in peripheral zone prostate cancer. Radiology 259: 453-61, 2011.

13. Kobus T, Hambrock T, Hulsbergen-van de Kaa CA, et al. In vivo assessment of prostate cancer aggressiveness using magnetic resonance spectroscopic imaging at $3 \mathrm{~T}$ with an endorectal coil. Eur Urol 60: 1074-80, 2011.

14. Turkbey B, Shah VP, Pang Y, et al. Is apparent diffusion coefficient associated with clinical risk scores for prostate cancers that are visible on 3-T MR images? Radiology 258: 488-95, 2011.

15. Watanabe $Y$, Nagayama M, Araki $T$, et al. Targeted biopsy based on ADC map in the detection and localization of prostate cancer: a feasibility study. J Magn Reson Imaging. 37: 1168-77, 2013.

16. Song I, Kim CK, Park BK, et al. Assessment of response to radiotherapy for prostate cancer: value of diffusion-weighted MRI at 3 T. Am J Roentgenol 194: 477-82, 2010. 
17. Quentin M, Schimmoller L, Arsov C, et al. Increased signal intensity of prostate lesions on high b-value diffusion-weighted images as a predictive sign of malignancy. Eur Radiol 24: 209-13, 2014.

18. Onal C, Sonmez S, Erbay G, et al. Simultaneous integrated boost to intraprostatic lesions using different energy levels of intensity-modulated radiotherapy and volumetric-arc therapy. Br J Radiol 87: 20130617, 2014. doi: 10.1259/bjr.20130617

19. Wu LM, $X u J R$, Ye $Y Q$, et al. The clinical value of diffusionweighted imaging in combination with T2-weighted imaging in diagnosing prostate carcinoma: a systematic review and meta-analysis. Am J Roentgenol 199: 103-110, 2012.

20. Thormer G, Otto J, Horn LC, et al. Non-invasive estimation of prostate cancer aggressiveness using diffusion-weighted MRI and 3D proton MR spectroscopy at 3.0 T. Acta Radiol 56: 121-128, 2015.

21. Bae H, Yoshida S, Matsuoka Y, et al. Apparent diffusion coefficient value as a biomarker reflecting morphological and biological features of prostate cancer. Int Urol Nephrol 46: 555-561, 2013

22. deSouza NM, Riches SF, Vanas NJ, et al. Diffusion-weighted magnetic resonance imaging: a potential non-invasive marker of tumour aggressiveness in localized prostate cancer. Clin Radiol 63: 774-782, 2008.

23. Mohler J, Bahnson RR, Boston B, et al. NCCN clinical practice guidelines in oncology: prostate cancer. $J$ Natl Compr Canc Netw 8: 162-200, 2010.

24. Engelbrecht MR, Puech $\mathrm{P}$, Colin $\mathrm{P}$, et al. Multimodality magnetic resonance imaging of prostate cancer. $J$ Endourol 24: 677-684, 2010.

25. Park SY, Kim CK, Park BK, et al. Early changes in apparent diffusion coefficient from diffusion-weighted MR imaging during radiotherapy for prostate cancer. Int J Radiat Oncol Biol Phys 83: 749-755, 2012.

26. Jung AJ, Westphalen AC. Imaging prostate cancer. Radiol Clin North Am 50: 1043-1059, 2012.

27. Bratan F, Niaf E, Melodelima C, et al. Influence of imaging and histological factors on prostate cancer detection and localisation on multiparametric MRI: a prospective study. Eur Radiol 23: 2019-2029, 2013.

28. Oto A, Yang C, Kayhan A, et al. Diffusion-weighted and dynamic contrast-enhanced MRI of prostate cancer: correlation of quantitative MR parameters with Gleason score and tumor angiogenesis. Am J Roentgenol 197: 1382-1390, 2011.

29. Woodfield CA, Tung GA, Grand DJ, et al. Diffusion-weighted MRI of peripheral zone prostate cancer: comparison of tumor apparent diffusion coefficient with Gleason score and percentage of tumor on core biopsy. Am J Roentgenol 194: 316-322, 2010.

30. Liu W, Turkbey B, Senegas J, et al. Accelerated T2 mapping for characterization of prostate cancer. Magn Reson Med 65: 1400-1406, 2011.
31. Foltz WD, Chopra S, Chung P, et al. Clinical prostate $\mathrm{T} 2$ quantification using magnetization-prepared spiral imaging. Magn Reson Med. 64: 1155-1161, 2010.

32. Haider MA, Chung P, Sweet J, et al. Dynamic contrast-enhanced magnetic resonance imaging for localization of recurrent prostate cancer after external beam radiotherapy. Int $\mathrm{J}$ Radiat Oncol Biol Phys 70: 425-430, 2008.

\section{Correspondence}

Dr. Cem ÖNAL

Baskent Üniversitesi Tıp Fakültesi

Adana Araștırma ve Tedavi Merkezi

Radyasyon Onkolojisi Anabilim Dalı

01120 Balcalı

ADANA / TURKEY

Tel: (+90-322) 3444444 / 1304

Fax: (+90-322) 3444445

E-mail: hcemonal@hotmail.com 